\title{
Evaluation of Barriers to Prevent Lead Contamination of Produce Grown in Urban Gardens
}

\section{Celine Richard, Kathryn Fontenot, Edward Bush, Heather Kirk-Ballard, M. Taylor Bryant}

School of Plant Environmental \& Soil Sciences, Louisiana State University Agricultural Center, Baton Rouge, USA

Email: crich99@lsu.edu

How to cite this paper: Richard, C., Fontenot, K., Bush, E., Kirk-Ballard, H. and Bryant, M.T. (2020) Evaluation of Barriers to Prevent Lead Contamination of Produce Grown in Urban Gardens. Journal of Environmental Protection, 11, 1064-1072. https://doi.org/10.4236/jep.2020.1112067

Received: November 20, 2020

Accepted: December 27, 2020

Published: December 30, 2020

Copyright () 2020 by author(s) and Scientific Research Publishing Inc. This work is licensed under the Creative Commons Attribution International License (CC BY 4.0).

http://creativecommons.org/licenses/by/4.0/ (c) (i) Open Access

\begin{abstract}
High lead $(\mathrm{Pb})$ contamination of soils is a threat to human health. Indirect ingestion occurs within the food chain through activities such as growing vegetables with an ability to accumulate lead in edible tissues. Many university extension systems recommend growing vegetables in raised beds to avoid lead contamination. However, there is limited scientific evidence of the efficacy of raised beds in reducing lead uptake in vegetable crops. To address the soil-lead exposure pathway from garden to consumption, this study supplements gaps in the literature pertaining to raised-bed garden practices by evaluating lining materials. Simulated raised beds were constructed to evaluate barriers (neoprene rubber sheeting, landscape fabric and a no barrier control) placed between contaminated (500 ppm) and uncontaminated garden media. The resulting data suggests that neoprene rubber sheeting is not an effective barrier to prevent lead uptake in vegetable crops. In fact, the neoprene barrier contained elevated amounts of lead contributing to higher levels of lead ( $\mathrm{p} \leq$ 0.05 ) within the plant tissue as compared to a no barrier treatment.
\end{abstract}

\section{Keywords}

Raised Bed, Chinese Cabbage, Heavy Metal, Soilless Media

\section{Introduction}

Lead $(\mathrm{Pb})$ is a naturally occurring heavy metal that exists at low concentrations (50 ppm) in the environment [1]. Throughout human history, Pb's prolific use has facilitated its relocation, concentration, and subsequent threat to human health. Through the phase-out of $\mathrm{Pb}$ use in products such as gasoline and paints, the amount of $\mathrm{Pb}$ used in the United States has generally declined since the mid-1970's. 
However, the residual effects of the $\mathrm{Pb}$ use in these and other industries have increased the levels of environmental $\mathrm{Pb}$ to which the average person is exposed [2].

Leaded gasoline emissions and $\mathrm{Pb}$ paint peeling in older buildings can result in suspension and further deposition of $\mathrm{Pb}$ on nearby surfaces [3]. Though $\mathrm{Pb}$ exists in various compounds, as a basic element it does not readily degrade in the environment and binds tightly to soils, therefore, contributing to its persistence as an environmental human health risk [4] [5].

Drinking, eating, and breathing particles containing $\mathrm{Pb}$ in any concentrations can result in acute or chronic $\mathrm{Pb}$ poisoning [2]. Many urban area soils are disproportionately contaminated with $\mathrm{Pb}$ from particulate dispersal via leaded gasoline emissions and $\mathrm{Pb}$ paint on older buildings. Older homes (built before 1978) and neighborhoods adjacent to heavily trafficked roads are often historically associated with marginalized and low-income communities [6]. In these communities and others, urban gardening is experiencing a resurgence in neighborhoods and schools as an educational tool for food, environmental, and nutrition literacy and self-sufficiency; therefore, an understanding of the state of soil contamination is vital to reduce or eliminate unnecessary food chain transfer of soil $\mathrm{Pb}$ to urban communities. Unfortunately, garden produce such as leafy greens and root vegetables have heavy-metal tolerance traits and can grow uninhibited by $\mathrm{Pb}$ and subsequently accumulate the heavy metal in their tissues [7] [8] [9]. The United States does not regulate $\mathrm{Pb}$ and other contaminants in produce. However, China released a standard for maximum levels of contaminants in foods in 2018. Per this regulation, the maximum concentration of $\mathrm{Pb}$ allowed for Brassica vegetables and leafy greens is $0.3 \mathrm{ppm}$ of total fresh weight [10].

For reference of "acceptable" soil Pb limits, The U.S. Environmental Protection Agency (EPA) set maximum bare soil $\mathrm{Pb}$ concentrations in federally funded project sites. Bare soil play areas and high-contact areas for children are limited to $400 \mathrm{ppm} \mathrm{Pb}$. The rest of the yard is allowed $1200 \mathrm{ppm} \mathrm{Pb} \mathrm{[11].} \mathrm{Various} \mathrm{Co-}$ operative Extension publications cite the 400 ppm EPA value of as the maximum soil $\mathrm{Pb}$ concentration considered safe to grow vegetables in soil. At any concentration above $400 \mathrm{ppm}$, an expensive remediation solution is excavation and removal of contaminated soils. Alternatively, the University of Connecticut Extension Service recommends growing vegetables in raised beds as a reasonable reduced risk option for avoiding $\mathrm{Pb}$ accumulation in garden vegetables particularly leafy greens and root vegetables [12]. These recommendations are consistent with those presented by other extension services throughout the country, specifically from Kentucky State, Oregon State, UMass Amherst and the University of Delaware [3] [13] [14]. All of these publications recommend growing in raised beds when yard soil contamination is above $400 \mathrm{ppm}$. However, overtime, risks to contamination of new, clean soil in a raised bed include resuspension of exposed surrounding surface soils, tilling too deeply into contaminated soil beneath the raised bed media or plants with deep roots, which may reach past the clean soil [15]. While both UMass Amherst and the University of Connecticut 
recommend using a liner under a raised bed to avoid the latter two mechanisms of resuspension, only the University of Connecticut specifies their recommendation as landscape fabric liner, though research based evidence was not cited [16]. Many studies have looked at $\mathrm{Pb}$ uptake and partitioning in plants and contaminated soils, but few studies have looked at physical barriers to limit or prevent $\mathrm{Pb}$ movement from contaminated soil into raised bed environments where produce is grown. Therefore, this study supplements gaps in current literature pertaining to use of barriers in a raised-bed garden in $\mathrm{Pb}$ contaminated areas. The objective of this study is to evaluate barriers to prevent $\mathrm{Pb}$ mobility from contaminated ground entering into the uncontaminated raised bed environment. Ideally, a specific barrier for lead exclusion will be identified.

\section{Materials and Methodology}

To simulate raised beds in a contaminated environment, large plastic containers (44 gallons, $133 \mathrm{~cm} \times 52.4 \mathrm{~cm} \times 35.6 \mathrm{~cm}$ ) (IRIS USA, INC, Surprise, AZ) were used. Plastic containers served as a closed system to prevent $\mathrm{Pb}$ from moving from the research area into the surrounding environment. Each container had a drainage hole at one end, 1.5 inches from the bottom, to allow for drainage. This hole was covered with landscape fabric to allow irrigation water to drain without media loss (Figure 1, Figure 2). Each container was elevated at a $10^{\circ}$ angle to encourage drainage (Figure 3 ).

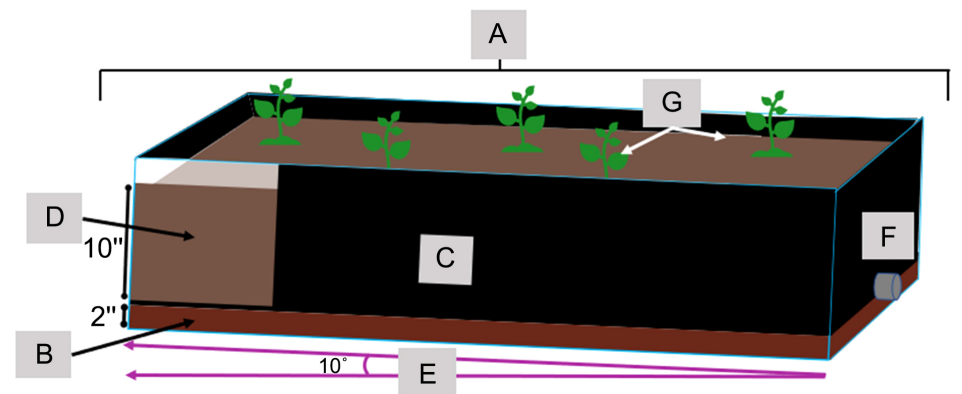

Figure 1. Diagram of raised bed experimental set up. (A) 44 gal plastic container (outlined in blue), (B) Contaminated media (500 ppm Pb), (C) Barrier treatment (cut away to show media profile), (D) Uncontaminated media, (E) Elevation gradient, (F) Drainage hole, (G) Brassica rapa 'Mibuna' plants.

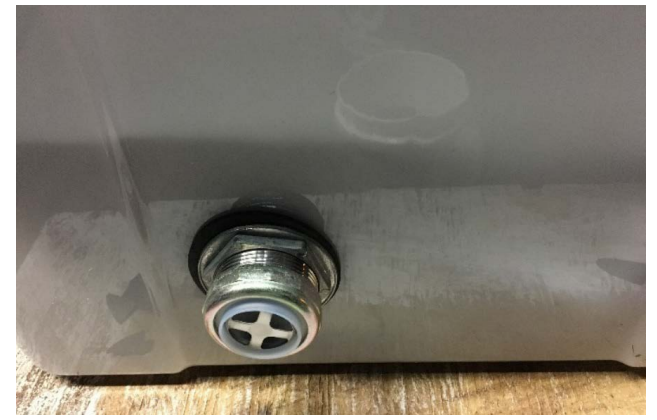

Figure 2. Drainage hole installed in plastic raised bed boxes. 


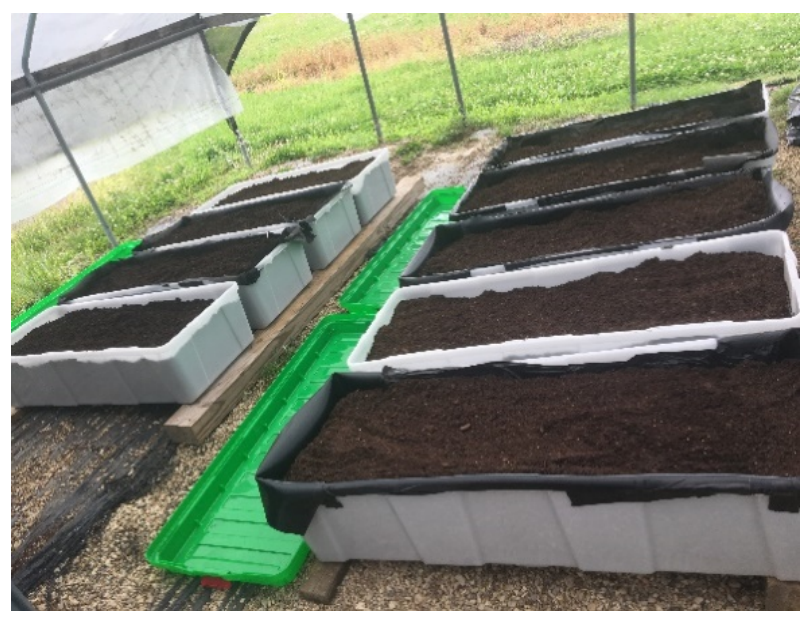

Figure 3. Experimental plot layout. Each plot is elevated at $10^{\circ}$ to promote drainage.

Within each container, contaminated media was layered to simulate contaminated ground soil and uncontaminated raised bed media (Figure 1). Between the media layers in each container, barrier treatments were applied (Figure 4). Barrier material treatments included Premlene ${ }^{\mathrm{TM}}$ Neoprene (New Orleans Rubber, Harvey, LA) (0.062 in, non-permeable), landscape fabric (Preen, Lebanon, PA) (0.019 in, permeable), and a no-barrier control.

The media used in this study is similar to standard potting mixes used in raised beds. Media was mixed in large batches using 4 cubic feet of peat moss (Lambert Peat Moss, Quebec, Canada), 18 cubic feet of 5/8th inch screened pine bark (Phillips Bark, Brookhaven, MS), 4 cubic feet of washed large grain sand (Baer Industries, Port Allen, LA), 10.5 pounds (4767 g) of Osmocote 19-5-9 (ICL Specialty Fertilizers, Summerville, SC), 0.5 pounds (227 grams) of Micromax (ICL Specialty Fertilizers, Summerville, SC), and 8 pounds (3632 g) of dolomitic lime (Lhoist, Port Allen, LA). Each treatment container was first filled with 5 gallons of contaminated media (500 ppm $\mathrm{Pb}$ ). To attain a final concentration of $500 \mathrm{ppm}$, media was spiked with a $10,000 \mathrm{ppm} \mathrm{Pb}$ standard in a $5 \%$ nitric acid $\left(\mathrm{HNO}_{3}\right)$ solution (RICCA Chemical Company, Arlington, TX) diluted to concentration using municipal water. Inductively coupled plasma-optical emission analytical spectrometry (ICP-OES) (PerkinElmer, Houston, TX) was used to analyze total $\mathrm{Pb}$ in media to confirm intended initial concentrations (EPA Method $3051 \mathrm{~A}$ ). The contaminated media layer was then covered and sealed to the edges of the containers using the experimental barriers (neoprene rubber, landscape fabric and no barrier control). After applying the barrier treatments, each container was filled with 15 gallons of uncontaminated media into which the experimental plants were to be grown (Figure 4).

All treatment containers were arranged in a complete randomized design (CRD) with three replications per barrier treatment. Brassica rapa (Chinese cabbage 'Mibuna') was selected to be grown out in the simulated raised bed conditions. Chinese Cabbage plants were replicated five times per treatment plot (Figure 1). 


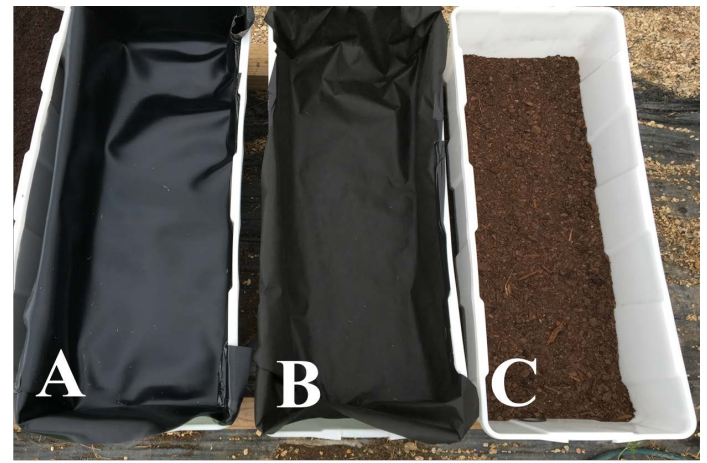

Figure 4. Simulated raised bed barriers applied to containers. Contaminated media sealed by selected barriers up to the top of each container's edge ((A) neoprene rubber; (B) landscape fabric; (C) no-barrier control).

Seeds of Brassica rapa 'Mibuna' were planted in 50 cell trays (T.O. Plastics Clearwater, MN) using SunGro Metro-Mix 830 (SunGro Horticulture, Agawam MA) on March 11, 2020 and April 11, 2020 and grown in a greenhouse. Temperatures through the first and second trials ranged between $53^{\circ} \mathrm{F}$ and $78^{\circ} \mathrm{F}$. Transplants were watered daily with overhead irrigation twice a day for five minutes. Transplants were fertilized using Peter's Professional ${ }^{\mathrm{TM}}$ water soluble 20-20-20 fertilizer (ICL Specialty Fertilizers, Summerville, SC) at 400 ppm every other week. The seedlings were thinned to one plant per cell. Two weeks after seeding, five plants were transferred into each raised bed treatment container at 12 inch spacings (Figure 1). These containers were located under a hoop house with open sides where temperatures ranged between $53^{\circ} \mathrm{F}$ and $78^{\circ} \mathrm{F}$. The plants were hand-watered daily and Bifenthrin insecticide (Fertilome, Bonham, TX) was applied at recommended rates to control aphids, (Brevicoryne brassicae), flea beetles (Phyllotreta striolata, Phyllotreta cruciferae), and cross-striped cabbage worms (Evergestis rimosalis).

After 30 days of growth in the treatment containers, all plants were harvested at the base of the stem and the above ground portion of the plant was weighed for fresh weight in grams. All plants were divided between two dryers (SHEL Lab and VWR Scientific Inc.) at an average of $60^{\circ} \mathrm{C}$ and dried to a constant weight before grinding through a $1 \mathrm{~mm}$ sieve in preparation for analysis. Inductively Coupled Plasma-Optical Emission Spectrometry (ICP-OES) procedure was used to analyze total $\mathrm{Pb}$ accumulated in the plant tissues (AOAC Method 985.01). The neoprene rubber sheeting was also analyzed for $\mathrm{Pb}$ content using a similar procedure as above.

A respirator and goggles were the personal protective equipment (PPE) used each time $\mathrm{Pb}$ standards and loose contaminated media were handled. Upon conclusion of this study, contaminated materials were disposed of by Louisiana State University Hazardous Waste Disposal (LSU Office of Environmental Health and Safety, Baton Rouge, LA). Data were analyzed with the statistical program SAS (version 9.2; SAS Institute, Cary, NC) Proc GLM with Tukey and Excel for Microsoft 365 (Microsoft Corporation, Redmond, WA). 


\section{Results and Discussion}

The effects of lead on final harvest weight of Brassica rapa did not vary significantly across barrier treatments which indicates that growth was not affected by the treatments applied (Figure 5). The large error bar values reflect the wide range of weight variability within each treatment (Figure 5 ).

Lead accumulation data suggests that neither neoprene rubber or landscape fabric significantly excluded lead uptake in Brassica rapa 'Mibuna' compared to the no barrier control treatment (Figure 6). There were no significant differences in $\mathrm{Pb}$ uptake between the neoprene rubber and landscape fabric barriers nor between landscape fabric and the no-barrier control treatment (Figure 6). Furthermore, the plants in neoprene and fabric treatments exceeded the reference value published by the Chinese National Food Safety Standard for maximum levels of contaminants in foods [10]. Not only did the neoprene rubber sheet treatment exceed the threshold discussed above, the accumulation reported in this treatment was significantly higher than the no barrier treatment.

Plausible explanations for the unexpected results include: pores in the landscape fabric may have allowed some contaminated soil movement; contamination could have occurred via the barrier materials themselves; or the plant roots did not grow deeply enough to reach the uncontaminated-contaminated media interface of the simulated raised bed to accumulate substantial lead in the plant tissues. ICP-OES extractions were subsequently carried out on the neoprene rubber revealing the material contained a concerning amount of lead (91 ppm $\mathrm{Pb}$ ), possibly contributing to the elevated lead accumulation in the Chinese cabbage plants. Studies of other systems which use neoprene corroborates this conclusion by demonstrating other occurrences of lead leaching from neoprene

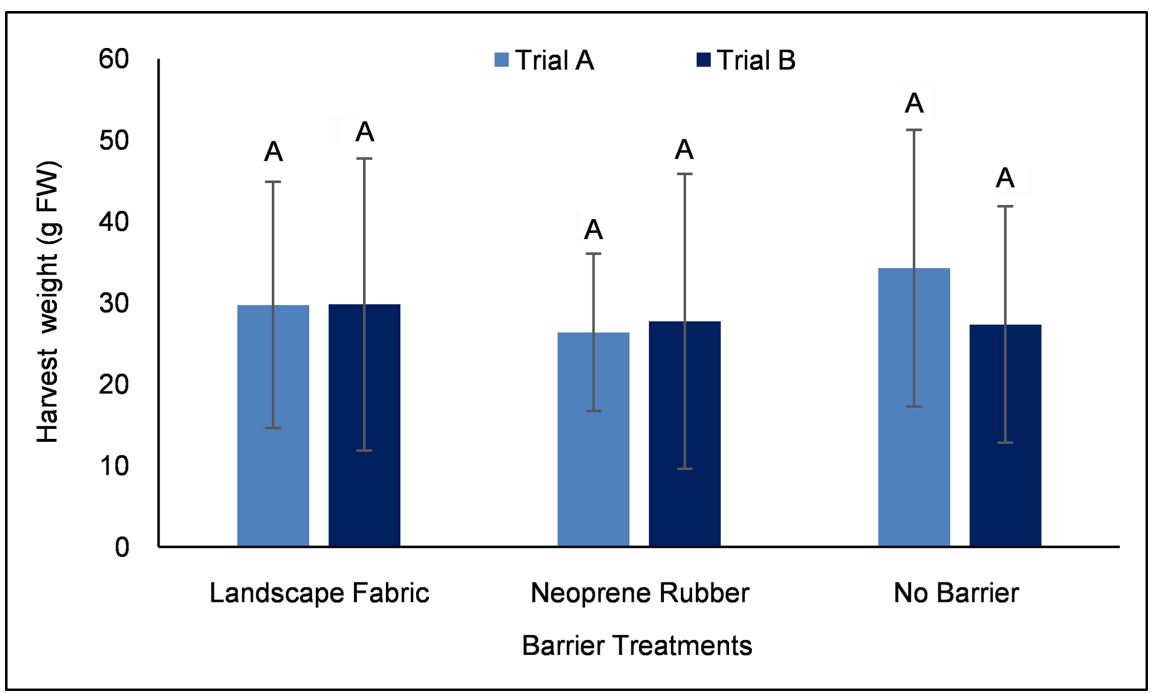

Figure 5. Harvest weight of Brassica rapa Chinese cabbage 'Mibuna' in Trials A and B across 3 barrier treatments (no barrier, landscape fabric, and neoprene rubber) over contaminated soil $(500 \mathrm{ppm})$. g FW = grams fresh weight. Letters indicate significant $(\mathrm{P}<$ 0.05) differences between treatments and trials. Bars that share the same letter are not significant. Error bars created using standard errors. 


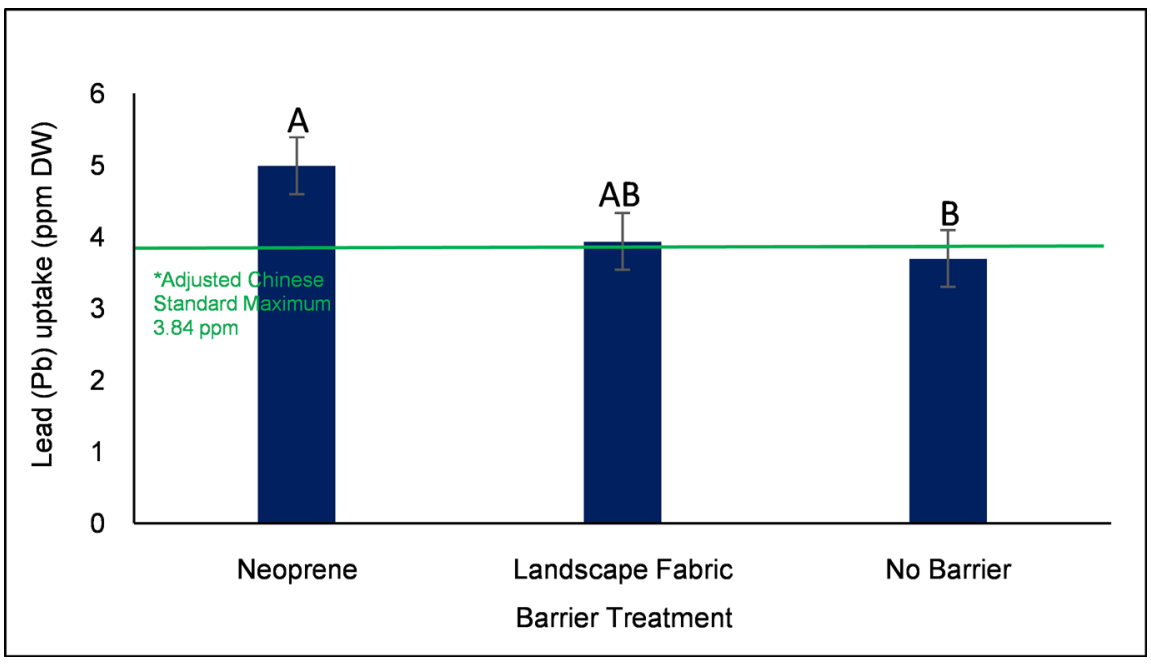

Figure 6. Lead $(\mathrm{Pb})$ accumulation in plants Brassica rapa Chinese cabbage 'Mibuna' grown in raised beds with barriers dividing uncontaminated and contaminated soil (500 ppm $\mathrm{Pb}$ ). Displayed data represents two replicated trials. PPM DW = parts per million dry weight. ${ }^{\star}$ The $3.84 \mathrm{ppm}$ DW standard displayed has been adjusted for reference from 0.3 ppm FW Chinese Standard for maximum $\mathrm{Pb}$ contamination [10] calculated for $92 \%$ moisture content of mustard. Letters indicate significant differences at alpha level 0.05 . Bars that share the same letter are not significantly different. Error bars were created using standard error.

materials [17]. Lead analysis was not performed on the landscape fabric because the accumulation data of the plant tissue did not indicate increased $\mathrm{Pb}$ levels in this treatment as compared to the control treatment.

Upon conclusion of this study, having no barrier is still not recommended as sufficient to prevent $\mathrm{Pb}$ uptake in vegetable crops. While the no barrier control treatment had similar $\mathrm{Pb}$ values as the landscape fabric treatment (Figure 6), further investigations of barrier materials is recommended. In this study, the plants were only allowed to grow for 30 days, whereas a homeowner may let them grow for 40 or 50 days. If plants were allowed to grow for a longer period of time, there is a chance that higher accumulation in the no barrier treatment may have been observed.

Future projects related to this research should evaluate other impermeable barriers such as other plastics like visqueen, and landscape fabrics of other densities as well as longer harvest intervals.

\section{Conclusion}

Contrary to expectations, neither neoprene rubber nor landscape fabric showed a decrease in lead levels in plants grown in experimental plots compared to the no barrier control. Further, plants growing in the neoprene rubber barrier treatment had significantly more $\mathrm{Pb}$ uptake than the no barrier treatment, implying that this treatment further contributed to raised bed $\mathrm{Pb}$ contamination. The significant increase in $\mathrm{Pb}$ uptake observed in the plants grown in the neoprene barrier treatment is likely due to $\mathrm{Pb}$ leaching from the barrier material. At 
the conclusion of this study, an appropriate barrier to prevent $\mathrm{Pb}$ uptake in vegetables was not found. Therefore, supplementary studies need to be conducted to analyze more barriers. Additionally, while the findings displayed in Figure 5 are consistent with observations that no treatment adversely affected plant growth, additional factors to consider for use of any impermeable barrier treatment include ensuring consistent efficient drainage. While there were no observable moisture retention issues for this treatment, this study was conducted in a controlled rain shelter environment, which would not be the case for the average urban gardener. If this study were to be replicated, standard procedure would include extending the growing season to give the plants more time to develop a root system into the contaminated layer and the addition of a fourth true control treatment without a contaminated base layer.

\section{Conflicts of Interest}

The authors declare no conflicts of interest regarding the publication of this paper.

\section{References}

[1] Pais, I. and Jones, J.B. (1997) The Handbook of Trace Elements. Saint Lucie Press, Boca Raton, 223.

[2] Agency for Toxic Substances and Disease Registry (ATSDR) (2019) Toxicological Profile for Lead. Draft for Public Comment. U.S. Department of Health and Human Services, Public Health Service, Atlanta. https://www.atsdr.cdc.gov/ToxProfiles/tp.asp?id=96\&tid=22

[3] Defoe, P., Presley, D. and Hettiarachchi, G. (2017) Gardening on Lead-Contaminated Soils. Kansas State University Agricultural Experiment Station and Cooperative Extension Service.

[4] Uzu, G., Sobanska, S., Aliouane, Y., Pradere, P. and Dumat, C. (2009) Study of Lead Phytoavailability for Atmospheric Industrial Micronic and Sub-Micronic Particles in Relation with Lead Speciation. Environmental Pollution, 157, 1178-1185. https://doi.org/10.1016/j.envpol.2008.09.053

[5] Xiong, J., Koopal, L.K., Tan, W., Fang, L., Wang, M., Zhao, W. and Weng, L. (2013) Lead Binding to Soil Fulvic and Humic Acids: NICA-Donnan Modeling and XAFS Spectroscopy. Environmental Science \& Technology, 47, 11634-11642. https://doi.org/10.1021/es402123v

[6] Mielke, H.W., Gonzales, C.R., Powell, E.T., Laidlaw, M.A.S., Berry, K.J., Mielke, P.W. and Egendorf, S.P. (2019) The Concurrent Decline of Soil Lead and Children's Blood Lead in New Orleans. Proceedings of the National Academy of Sciences of the United States of America, 116, 22058-22064. https://doi.org/10.1073/pnas.1906092116

[7] Capelo, A., Santos, C., Loureiro, S. and Pedrosa, M.A. (2012) Phytotoxicity of Lead on Lactuca Sativa: Effects on Growth, Mineral Nutrition, Photosynthetic Activity and Oxidant Metabolism. Fresenius Environmental Bulletin, 21, 450-459

[8] Liu, W., Zhou, Q., Zhang, Y. and Wei, S. (2010) Lead Accumulation in Different Chinese Cabbage Cultivars and Screening for Pollution-Safe Cultivars. Journal of Environmental Management, 91, 781-788.

https://doi.org/10.1016/j.jenvman.2009.10.009 
[9] Ramesar, N., Tavarez, M., Ebbs, S.D. and Sankaran, R.P. (2014) Transport and Partitioning of Lead in Indian Mustard (Brassica juncea) and Wheat (Triticum aestivum). Bioremediation Journal, 18, 345-355.

https://doi.org/10.1080/10889868.2014.933170

[10] Global Agriculture Information Network (GAIN) (2018) China Releases the Standard for Maximum Levels of Contaminants in Foods. FAIRS Subject Report. Global Agriculture Information Network (GAIN) Report Number: CH18025. USDA Foreign Agriculture Service.

[11] United States Environmental Protection Agency (EPA) (2013) Protect Your Family from Lead in Your Home. U.S. Environmental Protection Agency, Washington DC.

[12] Pettinelli, D. (N.D.) Lead in Garden Soils. Soil Nutrient Analysis Laboratory. University of Connecticut, Storrs.

[13] Brewer, L., Sullivan, D., Deol, P. and Angima, S. (2016) Reducing Lead Hazard in Gardens and Play Areas. Oregon State University Extension Service.

[14] Gartley, K.L. (2002) Managing Lead Contaminated Soils. Note 17. University of Delaware, Soil Testing Laboratory, Newark.

[15] Clark, H.F., Hausladen, D.M. and Brabander, D.J. (2008) Urban Gardens: Lead Exposure, Recontamination Mechanisms, and Implications for Remediation Design. Environmental Research, 107, 312-319. https://doi.org/10.1016/j.envres.2008.03.003

[16] University of Massachusetts Extension (UMass) (2017) Soil Lead: Testing, Interpretation and Recommendations.

https://ag.umass.edu/sites/ag.umass.edu/files/fact-sheets/pdf/sptnl_5_soil_lead_062 316.pdf

[17] Nunamaker, E.A., Otto, K.J., Artwohl, J.E. and Fortman, J.D. (2013) Leaching of Heavy Metals from Water Bottle Components into the Drinking Water of Rodents. Journal of the American Association for Laboratory Animal Science: JAALAS, 52, 22-27. 